\title{
Novitates Gabonenses (32) A new species of Panicum (Gramineae) from Gabon by
}

\author{
M.S.M. Sosef $(*)$
}

Résumé. - Une espèce nouvelle de Panicum, $P$. littorale, très proche de $P$. brazzavillense, est décrite de la savane côtière du Gabon.

During a study on the grass flora of Gabon (M.S.M. Sosef, in prep., Les Graminées de la région gabonaise: une actualisation de l'inventaire et des clés. Flore du Gabon), as an update to the treatment of Koechlin (Gramineae in Flore du Gabon 5), several specimens were encountered which were similar to Panicum brazzavillense Franch., but differed from this species, notably in the panicle being distinctly contracted and narrowly elliptic, sometimes almost linear in outline, only $2-5(-6) \mathrm{cm}$ long and densely spikeled. On further examination (which included material from WAG, BR and $\mathrm{K}$ ) it appeared that there were other characters that distinguished them from $P$. brazzavillense: the spikelets were always very small (1.0-1.2 $\mathrm{mm}$ long) and glabrous, the shearhs were distinctly shouldered, strongly striate and had glabrous margins, and the leaves were always stiff and inrolled. In $P$. brazzavillense the sheaths are not or slightly shouldered, have pilose margins and are less pronouncedly striate; the leaves are generally flat, and the panicle is open (or contracted only when young), usually larger and with slightly larger (1.2-1.7 mm long), hairy or occasionally glabrous spikelets. I therefore decided to describe this taxon, which appears to be endemic to coastal savanna's in Gabon from Port Gentil to Mayumba and is resistant to regular burning, as a new species.

There is one specimen that is difficult to place in either one of the two species: the type specimen of Isacbne filifolia Franch., Grif-

(*) Department of Plant Taxonomy, Herbarium Vadense, P.O. Box 8010, 6700 ED Wageningen (The Netherlands). - Manuscript received september 12, 1997. 
fon du Bellay 265, collected on the «Plaine de Denys», also situated in the coastal region of Gabon. The name was published in 1895 but already treated as a synonym of $P$. brazzavillense by $\mathrm{O}$. Stapf (Panicum in Gramineae, part 4, in D. Prain (ed.), Flora of Tropical Africa 9: 662-663. 1920), and also treated as such by i.e. W.D. Clayton \& S.A. Renvoize (Panicum in Gramineae (Part 3), in R.M. Polhill (ed.), Flora of Tropical East Africa: 476. 1982). The holotype and 2 isotypes from $P$ and an isotype from $K$ were available. Some of the culms are open, others contracted, even when mature. Most culms carry sparsely hairy spikelets, some glabrous ones. And finally, the sheaths are distinctly shouldered and glabrous, the spikelets small (1.1-1.2 $\mathrm{mm}$ ) and the leaves stiffly enrolled. The collection is not a mixture of both species, as i.e. some of the contracted culms bear hairy spikelets. One could of course launch the hypothesis that the collection originates from a «hybrid population ", but this seems a rather easy way out. I just have no explanation yet; I may have the opportunity to study the plants at the Pointe de Denis soon. As there is a comparatively large number of correlated characters that distinguish the new species from $P$. brazzavillense, I decided to maintain this species as new despite of this apparently intermediate collection. Besides that, when it would become evident in the future that the collection (or part of it) belongs to the new species, the epithet cannot be transferred to $P$ anicum as the name $P$. filifolia was already used by W.D. Clayton for a different species. In that case one is allowed to describe the species as new as well.

Panicum littorale Sosef sp. nov.; Panico brazzavillensi Franch. affinis, sed panicula valde contracta et anguste elliptica atque spiculis glabris minoribus, etiam margine vagina folii glabro et apice vaginae manifeste auriculato differt. - Fig. 1.

Perennial, somewhat glaucous-green grass forming dense tussocks; culms erect, slender, $25-45 \mathrm{~cm}$ tall. Leaves mostly basal; sheaths strongly striate, glabrous, distinctly shouldered at apex, basal ones often purplish; blades stiff and inrolled, $5-20 \mathrm{~cm}$ long, 0.5-1.0 mm wide, glabrous except for some minute hairs along the margin at base; ligule c. $0.5 \mathrm{~mm}$ long, minutely puberulous on the side facing the blade. Panicle slightly to long exserted, distinctly contracted and densely spikeled, $2-5(-6) \mathrm{cm}$ long, $0.5-0.8(-1.3) \mathrm{cm}$ 


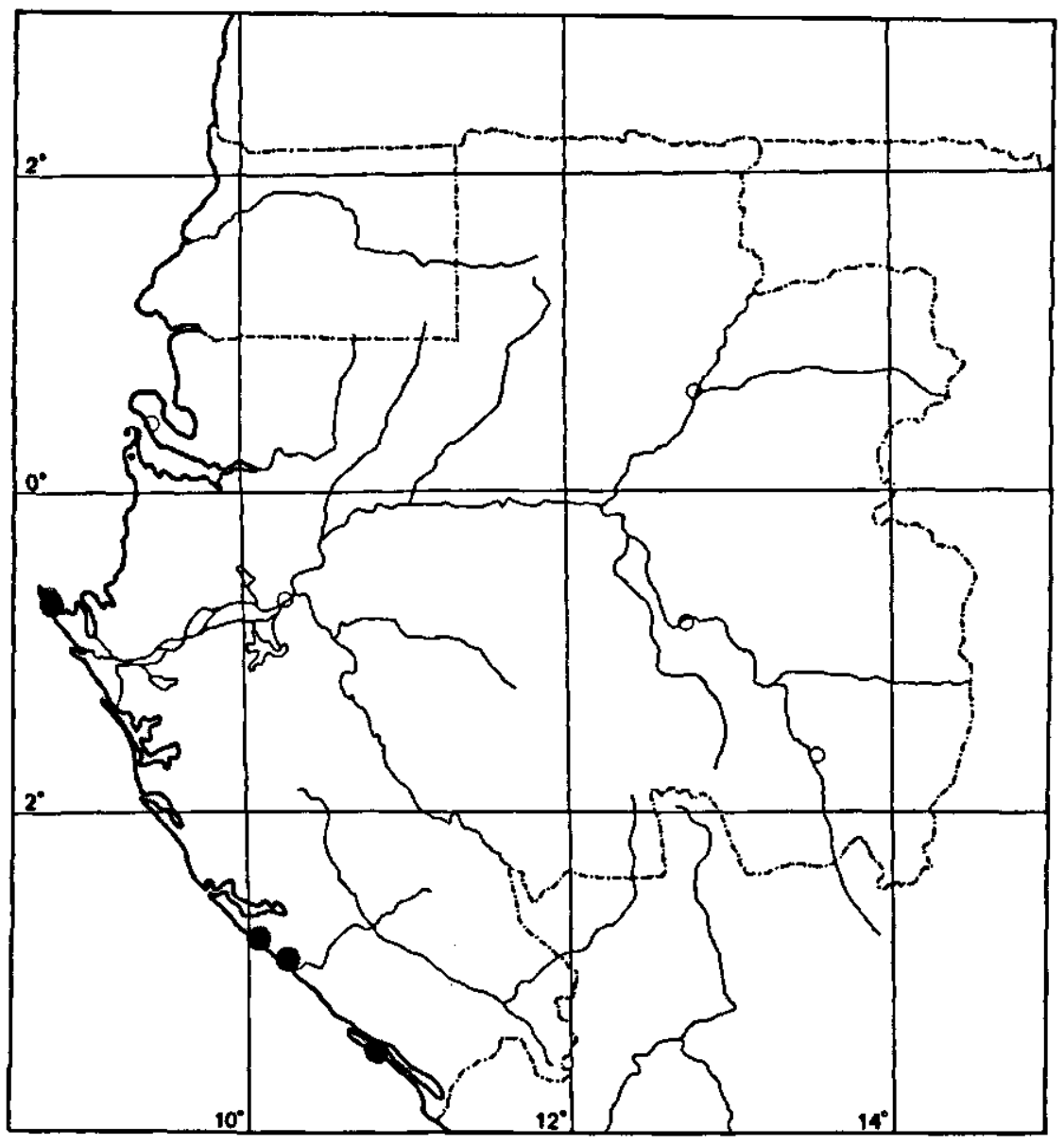

Fig. 1. - Distribution of Panicum littorale; question mark referring to Griffon du Bellay 265 as discussed in the text.

wide; branches wiry and flexuous, lowest primary branches reaching about halfway up the panicle. Spikelets broadly ellipsoid or broadly ovoid-ellipsoid to globose, $1.0-1.2 \mathrm{~mm}$ long, slightly asymmetric, glabrous, 2 -flowered, lower floret male, upper female; lower glume ovate, c. 3/4 as long as the spikelet, slightly saccate at base, 3- or 5-veined; upper glume broadly ovate, as long as the spikelet, 5-veined; lower lemma almost equalling the spikelet, similar to the upper glume; upper lemma globose, c. $0.6 \mathrm{~mm}$ long, indurated, white, verrucose; lower palea curved over the female 
flower, leachery, with 2 broad hyaline margins that clasp the anthers; upper palea flat, indurated.

GABON: SE of Port Gentil, 16-9-1968, c. $0^{\circ} 40$ S $8^{\circ} 50 \mathrm{E}$, fl., Breteler \& van Raalte

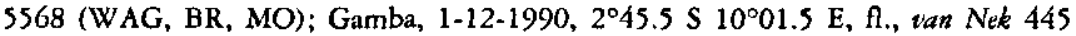
(WAG, LBV); ca $5 \mathrm{~km} \mathrm{~S}$ of Yenzi, 22-3-1991, $2^{\circ} 48.7 \mathrm{~S} 10^{\circ} 02.8 \mathrm{E}$, fl, van Nek 738 (WAG, LBV); Mayumba-peninsular, about $15 \mathrm{~km} \mathrm{~S}$ of Mayumba, 18-2-1983, $3^{\circ} 30 \mathrm{~S}$ $10^{\circ} 45$ E, fl., J.J.F.E, de Wilde, Arends, Louis, Bouman \& Karper 635 (WAG, BR, LBV, MO); Gamba, $13 \mathrm{~km}$ from airport at Gamba along the road to Mayonami, 22-11-1994, $2^{\circ} 52 \mathrm{~S} 10^{\circ} 08 \mathrm{E}, \mathrm{A} ., J . J . F . E$. de Wilde \& de Wilde-Bakbuizen 11150 (holotype WAG, isoBR, K, LBV, MA, MO, NY, P, PRE).

Acknowledgements: The curators of the herbaria at Meise (BR), London $(\mathrm{K})$ and Paris $(\mathrm{P})$ are gratefully acknowledged for the loan of material. Dr. A. Leeuwenberg kindly translated the diagnosis into Latin. 